\title{
An Overview of Strategic Information Systems Planning in Banking Sectors: A case study of Riyadh Bank of KSA
}

\author{
Wejdan Bajaber \\ Information Systems \\ Department, \\ Faculty of Computing and \\ Information Technology, \\ King Abdulaziz University, \\ KSA, Jeddah
}

\author{
Manahil AIQulaity \\ Information Systems \\ Department, \\ Faculty of Computing and \\ Information Technology, \\ King Abdulaziz University, \\ KSA, Jeddah
}

\author{
Aasim Zafar \\ Information Systems \\ Department, \\ Faculty of Computing and \\ Information Technology, \\ King Abdulaziz University, \\ KSA, Jeddah
}

\begin{abstract}
Use of information systems and information technology is always gaining momentum not only in companies but even in the banking industry which are determined to utilize it properly. This research critically reviews the literature relating to the SISP in Banking Sector. This paper aims to focus on the aspects of strategic planning system as it is applied in the banking sector in general. A case study is presented for Riyadh Bank to investigate their strategic planning.
\end{abstract}

\section{General Terms}

Information Systems, Strategic Systems Planning, Information Technology, Banking.

\section{Keywords}

Information Systems strategy, Information Technology, Banking sector, SISP

\section{INTRODUCTION}

Strategic information systems planning (SISP) has become a relevant aspect in the banking sector in the last few years. Most of the financial service providers are determined to ensure that they increase the efficiency that is associated with their services (Laudon \& Laudon, 2014). Majority of the leading banks have now come up with the prospect of building their activities on information technology (IT) and considering the importance of IS/IT in banking processes, they have reserved positions for the head of IT strategy and/or the director of strategic IT management (Timmers, 2013; Ukai, 2015). This research attempts to analyze the aspects of strategic information systems planning in the banking sector, and a case study of Riyadh Bank is discussed to investigate the bank strategies in different areas. This research incorporates literature review where it focuses on the research activities that have been undertaken in the same line of study. Emphasis is given to understand the milestones that have been achieved in the field with the view of analyzing the impact that strategic planning in the information system has had on the activities in the banking sector

\section{OVERVIEW OF IS/IS IN BANKING SECTOR}

A strategic information system planning is an area of critical concern among managers in financial institutions. Information systems strategies have enterprise-wide relevance and a high business impact hence there is a need to develop reliable strategic information system plan. A bank's strategic information systems plan ensures that the firm's IT investments are aligned with the entire business strategy. A well-designed information system strategic plan will give a bank competitive advantage over others, improve and enhance the banking processes, increases the productivity and performance of the employees, and also help the bank develop new businesses.

For a bank to gain the associated benefits, they need to be competitive in four areas. These fields include a proper technology strategy, Organizational structure and accountabilities, bank strategy development process and information system Responsibilities, and policies (Pita, Cheong \& Corbitt, 2010). The banking industry is information-intensive and highly dependent on the information systems as a core component of efficient service delivery.

The banking sector has different critical activities that require to be included in any strategic information system plan These include:

- Product development: Population and demographic factors keep on changing. The evolution of customer demands requires new products to be developed. Banks analyze the existing products against customer demands and launch new products across all the branches. The process of devising a new product can be rigorous and time-consuming. If the product development takes too long, the competitors will take advantage. At the same time if inadequate information is passed to employees at different branches the bank risk losing business and money. Information systems are used to ease the process of decision making. Decision support making systems help the managers to make a decision on which new products will do well in the market. Decision support systems are knowledge base systems that store prior information on different scenarios and different results. Managers do not need to analyze massive volumes of data to come up with the best products to roll out. The system does the necessary analysis and proposes the possible improvements or reductions that are necessary to improve the available products. Through the use of the management information systems, managers can cut decision-making period, which give the bank competitive advantage over others.

- Sales and marketing: Once products are developed it is critical for banks to market and avail them to different customers. The marketing department is essential in any bank. Technology has made 
commercialization of different product easier and cheaper to undertake. For a long time, banks have relied on the mainstream media to promote their products. Technological advancement has however changed this. Social media emails and short messages have also been adopted as a way of creating customer awareness. Most of the banking systems are integrated with these media making broadcasting of information cheaper and accessible to the larger population.

- Operations and service delivery: Internal banking transactions that include the opening of a client account, debiting, and crediting of different customer accounts are fundamental processes in any bank. The operations are achieved through customers visiting a physical branch where a teller assists a client, or a customer uses automated teller machines to access services. The two approaches have for long been associated with a lot of inconveniences that result from the long queues due to few service points. Use of technology has however changed how a bank delivers services. Through the use of internet banking, mobile banking and agency banking services have been brought closer to customers.

- Performance monitoring: The bank management needs to have a mechanism for ensuring efficient service delivery. Different department and branches have set targets to meet. Technology has provided tools for monitoring the various market parameters that affect performance. Through the use of banking information systems, the management can monitor individual employee performance. They can also evaluate individual branch performance and make appropriate management decisions. Information gained from such performance evaluation tools can be used to determine which branches to retain and which one to close down. Closing down underperforming branches helps the bank to maintain a lean staff which leads to increased profitability. Performance monitoring tools help the bank in risk analysis reducing the probability of the bank losing money or business due to engagement in risky business activities. Performance tools have also been used in reducing the risk of losing money through fraudulent activities as the inbuilt tools can raise alerts when suspicious activities are detected.

\subsection{SISP in Banking Sector}

The mission of the strategic information systems plan is to add value to the banks products through faster delivery of services in a cost-effective way. The strategic plan will place main emphasis on the following:

- Maximize the productivity of the bank staff.

- Provide quality services to the bank customers.

- Minimize the cost and complexities of banking processes.

- Help the bank attract and retain highly skilled staff.

- Assist the banks attract and retain new customers

To enable the bank grow and meet the changing customer requirement, the departments will need to practice teamwork, integrity, service ownership, understanding the client's business, professional development, and understand the bank information systems well. To deliver the expected result the following strategic goals need to be achieved:

- Innovations to promote access to bank service from anywhere.

- Improve bank resource utilization management

- Improve infrastructure stability system reliability

- Develop green Banking through reduced paperwork.

The detailed information systems plan:

\begin{tabular}{|c|c|}
\hline Expected Outcomes & Detailed Goals \\
\hline $\begin{array}{l}\text { Innovations to } \\
\text { improve access to } \\
\text { banking services }\end{array}$ & $\begin{array}{l}\text { - Introduce more applications for } \\
\text { mobile banking. } \\
\text { - } \\
\text { Develop more modules for internet } \\
\text { banking } \\
\text { - Introduce agency banking }\end{array}$ \\
\hline $\begin{array}{l}\text { Promote bank } \\
\text { resource } \\
\text { utilization } \\
\text { management } \\
\end{array}$ & $\begin{array}{l}\text { - } \\
\text { Provide for shared office resources. } \\
\text { Develop resource allocation and } \\
\text { monitoring tools }\end{array}$ \\
\hline 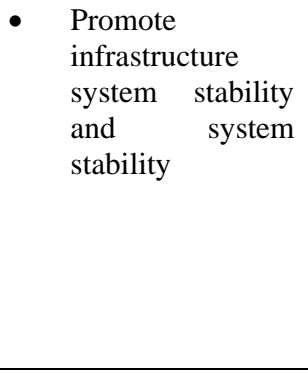 & 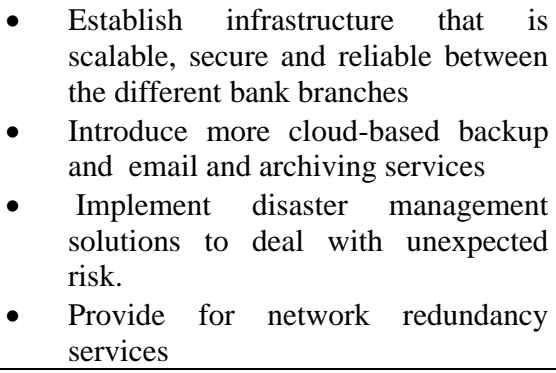 \\
\hline $\begin{array}{l}\text { Promote green } \\
\text { banking practices }\end{array}$ & $\begin{array}{l}\text { - } \quad \text { Reduce paper-based transactions } \\
\text { - Encourage use of mobile and internet } \\
\text { banking }\end{array}$ \\
\hline $\begin{array}{l}\text { Delivery of } \\
\text { quality services }\end{array}$ & $\begin{array}{l}\text { - Adoption of Information Technology } \\
\text { service management that are } \\
\text { ISO(international organization of } \\
\text { standardization) certified } \\
\text { - Reduce the single available point of } \\
\text { failure in the systems } \\
\text { - Provide for system monitoring tools } \\
\text { for detection and prevention of } \\
\text { system failures }\end{array}$ \\
\hline
\end{tabular}

To achieve the stated goals of strategic plan, both long term, and short term objectives are developed and employed.

\section{Short-term objectives:}

1. Training of the banking staff to equip them with the content of the strategic plan. Employee training will promote ownership of the strategic plan and hence make it easier for the employees to implement the plan.

2. Development and implementation of the share resource policies to guide how resources will be shared.

3. Education of customers to boost acceptance and adoption of the internet and mobile banking services.

4. Initial backup services can be provided through leasing of facilities. 


\section{Long term objective:}

1. To reduce the queue length and bring services closer to the consumer, the bank will explore on modalities of developing and deploying agent and mobile banking. Mobile and agency banking will reduce the number of customers visiting the banking hall and boost customer service delivery.

2. Investment in redundant infrastructure and personal cloud services will help achieve reliable network connectivity and systems stability. Resource ownership will reduce the cost incurred in leasing and ensure quality service delivery.

3. The bank in future will need to recruit staff with relevant skill. Staff with appropriate skill will reduce the cost of training.

Adoptions of appropriate strategic information systems plans lead to reduced cost of doing business. This is as a result of a reduction in transaction costs, lean staff as a result of improved employee's efficiency, reduced infrastructure cost, and reduced systems down times. All these factors lead to improve customer service delivery. However, high-quality services create a competitive advantage over other banks. Banking depends on customer trust to grow their client-base. Improved service delivery builds client loyalty that in turn secures a bank's continued growth.

In general, the banking industry needs to develop platforms that are uniform, this way banking services can be shared across different outlet despite being offered by different banks. The Visa and MasterCard services provide a crossplatform for unified money access from a pool number of access points. A similar approach should be adopted in mobile and internet banking. Integration of mobile and internet banking services will reduce the cost of doing business due to reduced number of staff and improved efficiency.

\section{Benefits of strategic planning}

It is mentioned that to guarantee the growth of the organization and improve the profits, formal planning should be followed, also by following strategic planning many benefits on the organization performance will be gained (Abdalkrim \& Khrais, 2013).

Benefits includes the following:

- It supports the organization's activities.

- It gives the managers the ability to put clear goals and method to achieve them.

- It provides more information which improves the decision making process and save time.

- It enables managers to predict problems before they happen which also decrease the mistakes possibility.

- Increase the change adaptability.

- Provides future goals and directions, and standards to reach them.

According to Abdalkrim and Khrais, Organizations should create strategic planning for many reasons which include the following:

- Clarifying the consensus on the organization strategy and fill the gaps of any possible questions.
- It allows all levels of the organization to be involved, support compatibility between the personal and professional goals through the overall vision of the organization.

- Clarify how strategic should be initiated so they don't get conflict with each other. Guide decision making by organizations members.

- Set the resource allocation which improves the budget. Measure and evaluate the progress of the organization to reach its vision.

- Put out all the organization`s opportunities.

- Improve the organizational performance effectiveness through direct the human skills and knowledge to the proper position.

- Keep the organization abreast of the market change which improve its stability in the marketplace.

\section{SISP IMPLEMENTATION IN THE BANKING SECTOR}

This section will investigate real life example of SISP implementation in the banking sector from different country.

\subsection{Banking in Korea}

Strategic planning has been widely considered by most of the institution around the world. Most of the banks has applied strategic planning concept, tools, and techniques in which to fulfill their mission and vision. Kwangju Bank, in southwest Korea, had a real challenge in implementing an effective SISP. The existing systems was on-line system, they developed their original client/server system from the bottom up, which is a separate, non-integrated systems. Changes to a business object in one system required a change to be done in other system version that increased the employees, the workload and processing time. They had to change their existing system and replace it with a well-integrated, flexible, speedy, and up to date system technology. Where all systems work independently while also they share data. They realized that they need to change the systems by using a new integrated strategic data model that reflect their business strategies and requirements for the next decades. Building a platform-independent enterprise information architecture that would give it cross-functional, non-redundant systems and databases that meets the requirements. A vendor presented a technique to develop a Strategic Information Systems Plan with full documentation in one month maximum. They first defined their critical elements (customer, market need, and business rules that apply), from that they established a strategic model and a strong plan for developing wellintegrated systems in the most critical areas: financial management, customer management, and marketing. Strategic model was developed using the Visible Advantage Enterprise Engineering tool, to analyze data models and identify crossfunctional practices that specify business-reengineering opportunities. Diagram of entities and business rules was provided and defined in the strategic management meeting so it makes it easier to review business concepts and relationship. It derived sub-project from the strategic model that can identify from 70-8- sub-projects and project plans. It helps the decision maker in which priority system must be implemented first. it identifies prerequisite data and common processes that are shared through the enterprise and changes in any business object is reflected directly to all part of the enterprise system. Visible Advantage uses Entity Dependency to identify crossfunctional business objects automatically that then identifies 
common reusable processes, the data required by each particular process, and prerequisite. The SISP eliminated the redundancy and provided a firm foundation for developing plans for databases and systems. SISP will allow the bank to selectively and easily upgrade its integrated systems without having to rebuild all its systems from scratch (Finkelstein, n.d.).

\subsection{Banking in Lebanon}

Another example of successful SISP implementation on banking sector was the Lebanese case. During the last civil war most of the infrastructure was destroyed and the banking sector was heavily affected. Information technology was not presented and they had to implement a strategic plan to install information technology at all stages, Transactional, Managerial, and Executive level. They believed of the necessity of IT in improving the work organization and delivering the best services to their customer. Many reasons involved in the need of developing a new Information System in banking sector; Quick land development has constrained banks to substitute their off-line systems by an on-line framework connecting the branches to the head office through the information transfers system, diminish staff costs which constitute a vast part of the working expenses by rebuilding bank's procedures with a specific end goal and a substantial weight on its working benefit. Also, the need to be up to date in technology and incorporating new advancements like ATMs, tele banking, etc. so they can provide high quality services to the customers and to stay competitive in the marketplace and foreign banks.

As a first step Lebanese Banks started with building the database and automating the work procedure. Ready-made packages was the choice of most of the banks for their internal operations. Ban k Audi bought an on-line data framework giving a constant on line branch system with an up-to-date banking and customer information to all managerial level, end users and business analysts, while some other banks like Banque du Liban et d'outre-mer (BLOM), for instance, has developed its own whole banking information system.

The bank branches planned to provide state-of-the-art services to their customers permitting a fast growth of the bank's performance in a very competitive marketplace. In 1993 Arab Bank was the innovator in introducing ATMs in Lebanon and install it. Other banks followed, by founding in 1994 a network called Link Network, using Link cards. Remote banking services was also introduced; Arab bank was the initial bank to offer this service. Also, voice response system was introduced by the early 1994 by Arab bank as well as a services called Corporate banking which is computer based remote service. Other banks, Allied Business Bank, BLOM, Universal Bank, and the British Bank of the Middle East presented their telephone based remote banking. However, these services were off-line systems that provide only inquiry facilities. Telecommunications infrastructure played major role in the failure and success of IT implementation, another difficulty is managerial practices and organizational weaknesses.

The Lebanese telecommunications infrastructure was damaged by the civil war, reintegration and modernization of this infrastructure started in 1993. The recovery plan developed by Council for Development and Reconstruction (CDR) illustrated that, the bank can rely on public network in 1998 upon the completion of the plan. The implementation of services and products such online banking, electronic money transfer, real time bank information systems will be delayed.
They conducted a feasibility study of installing a private telecommunications network to overcome this situation. Four banks were involved in this matter Bank Audi, Arab Bank, Byblos Bank, and BLO. They faced three obstacles for implementing such a network:

- Attaining a license from the Ministry of Post and telecommunications.

- The high cost of the equipment

- The lack of coordination between the members of the Lebanese Banks Association. (Ghaziri, 1998)

Despite the challenges the banking sector in Lebanon faced, they Provision nowadays of traditional and modern services of which: ATM, Card services, and online Banking.

\subsection{Banking in UAE}

Citibank is a subsidiary of Citigroup, Present in the United Arab Emirates since 1964. Citibank has been seen, as at the edge of advancement utilizing its worldwide expertise, it was the first bank in the UAE to present innovative e-business solutions like: Citi Phone - 24-hour Phone Banking Service, ATMs, Citi Alert -GSM notifications service, E-Card Internet Shopping Card, Citi Direct - Corporate Internet Banking Service, and Citibank Online - Retail Internet Banking Service.

Considering the tremendous growth of internet usage and the statistic done by Etisalat (UAE Internet Service provider) in 2003 , the number of internet user represent almost $30 \%$ of the population. Mobile phone users have a high percentage compared to the population. Citibank wanted to be innovative by following differentiation strategy of being the first international bank to launch a multifunctional online banking services and own the category before competition becomes wild in the sector. By offering a greater web banking option with capable and significant functionalities where clients get to work and access their accounts in a convenient way. The strategy focused in achieving the following objectives:

1) Spread its system and conquer the restricted division circumstance.

2) Attain funds in Citi Phone/Branches' working expenses by occupying clients to the Internet. Citibank Online has one of the least "expenses per

3) Association" as contrasted with the ATM, telephone managing an account or branch saving money. It contributes enormously as a component of the Strategic Cost Management activities the bank is actualizing without bargaining on the quality of service.

4) Fulfil the customer demand for secure, quick and convenient banking services to stay competitive.

5) Improve the brand imagery and values in the mind of the customers.

6) Creating and deepening the customer relationship through cross sell and procurements of new customers.

As part of the pricing strategy, Citibank reduces the price of all the services if used in online Citibank. Security issues were addressed through Secure Socket Layer (SSL) encryption, firewalls to prevent unauthorized access, online session is open by using a password entered by the user, and an 
automatic 'timeout' feature if no action was spotted for a specific time period.

Citibank aims to allow its customers to access and manage their relationship with the bank by a click on mouse button while maintaining privacy, accessibility and security of information. The e-business model consists of three elements: value stream, revenue stream and logistics stream. Adding value to its customer was certainly the main focus of Citibank by offering distinguished services among other competitor. Its interior logistics were associated towards a single objective; initiation a powerful service to its customers to supplement its e-business strategy. Revenues by the time started to increase, and the investment payoff. The e-business model used by

Citibank can be classified as "Merchant" as the following table shows:

\begin{tabular}{|l|l|}
\hline Brokerage & $\begin{array}{l}\text { Market makers getting together buyers and } \\
\text { sellers and facilitating transactions. }\end{array}$ \\
\hline Advertising & $\begin{array}{l}\text { A web-advertising model and extension of the } \\
\text { traditional media broadcasting model where } \\
\text { websites provide content and services and } \\
\text { advertising messages. }\end{array}$ \\
\hline Merchant & $\begin{array}{l}\text { Retailers selling goods directly to buyers } \\
\text { (Citibank Online) }\end{array}$ \\
\hline Infomediary & Collecting and distributing information \\
\hline Manufacturer & $\begin{array}{l}\text { Manufacturers using the web to reach buyers } \\
\text { directly, eliminating wholesalers and retailers. }\end{array}$ \\
\hline Subscription & $\begin{array}{l}\text { Payment of fees to access information or } \\
\text { services. }\end{array}$ \\
\hline
\end{tabular}

One way to evaluate the Citibank strategy is the financial performance, Ms. Sarah Hussain, Web Administrator at Citibank says "The results of the service represented in the information management system reports covering the performance of Citibank Online from 2001 to 2004 are very satisfactory and have met the management's expectations". The number of active users increased from $2 \%$ in the second year of the start to $6 \%$ in 2004 , also online transactions increased which shows that the customer are comfortable managing their accounts and funds through the internet, indeed the huge investment for awareness and advertising assigned from the budget worthwhile. Online banking has proving to be a successful accomplishment and revenuegenerating channel, the degree of innovation and The extent to which the new functions are integrated within the business model are two dimensions illustrated by Timmer (1999). Citibank was innovative and surpassing in structuring and sustaining the competitive advantage in the Internet age, all functionalities offered were perfectly integrated with the ebusiness strategy. They contribute straight towards meeting the objectives (Al-Mudimigh. A, 2007).

\section{RIYADH BANK-A CASE STUDY}

The annual reports for the year 2010, 2011, 2012, 2013 and 2014 were studied and analyzed for the purpose of identifying the strategic planning of Riyadh bank of KSA. A brief analysis and discussion related to bank's strategies is given below.
While there have been tremendous achievements made by Riyadh Bank over the past few years, this part focuses on the main accomplishments and the primary strategic plans which facilitated accomplishments. On the turn of the year 2010, major advances were made by the bank towards achievement of its primary objectives of raising customer services provision and increase the level of satisfaction. They were ranked as number one ATM services provision network with an exemplary level of machine distribution (Riyadh Bank Annual Report 2010). The strategic objectives included are inclusive of but not restricted to bank assets while preserving the asset quality and capital base while ensuring maximum returns to its shareholders. Performance improvement has seen the bank continue with its performance transformation program that has helped the company exceed consumer expectations. The strategies have been achieved through use of databases and information program to help increase customer satisfaction. Community services have also been extensively developed through societal activities that include charitable activities. The importance of organ donation has been raised through an awareness campaign with community service departments that support women campaigns. Care and special needs through equipment that meets the needs of the consumer is also a core social responsibility measure that has been undertaken. The financial performance of the bank indicates that the Bank net income decreased by a total of $6.8 \%$. Assets fell by a total of $1.6 \%$ (Riyadh Bank Annual Report 2010). Loans and advances decreased by a total of $0.5 \%$. Investments grew by a total of $4.7 \%$ while customer deposits continued to increase by a total of $1.3 \%$ (Riyadh Bank Annual Report 2010).

In the year 2011, Riyadh Bank had core strategies which were intended to improve and to increase the assets as well as ensuring high quality of assets has been maintained. Furthermore, the objectives were oriented at making the market share improved and incorporation of retail banking. Being high ranked in the economy, the major struggle would be remaining powerful. On that basis, the bank intended to retain its position and hence its leadership in the economy. Social responsibility is also among the key aims of the bank. Attaining of this objective has been aided by the use of various programs that have been completed and association in charitable events. Education and cultural aspects have been managed through activities that support careers in the Riyadh capital that honor top students. Retail services in the year 2011 were improved as its core activities that were delivered and executed in relation to consumer needs. Corporate banking services have been met by the improvement in IT governance through the use of an IT governance program that improves the management aspects of banks (Riyadh Bank Annual Report 2011). Credit ratings for the bank were maintained despite the turbulence in banking sector. Financial performance of the bank in the year 2011 indicated an increase of $11.5 \%$. Operating incomes were also on the surge improving by $5.7 \%$. Total assets of the bank grew by $4.2 \%$ in the year 2011 from the previous year. Market Share has grown with customer deposits increasing by $6.5 \%$ (Riyadh Bank Annual Report 2011).

In the year 2012 there were plans to grow incomes and this was achieved. Statistics further show Riyadh Bank has maintained its leadership in the kingdom with many customers approving its services in personal finance, private investments funding, and corporate financing (Riyadh Bank Annual Report 2012). The government has also benefited via loans to finance infrastructures and massive development initiatives. Other strategic initiative by the bank includes 
social welfares, foreign expansions, and technological advances. The main achievements are the increase in income and reputation growth in its market. Among the most notable strategic plan changes includes, but are not limited to; strengthening its resources and increasing its capital base. Growth in the technological sector was also amongst the fundamental goals that the bank wanted to attain. Continuity in customer service satisfaction and improvement of competitive capabilities were the core strategic functions of the bank in the same period.

As the years progressed, the objectives of the bank were noted to change too. By the year 2013, the primary objectives entailed usage of customer satisfaction programs. More focus was addressed at diversifying business operations well as expanding its areas of operation. SAMA issued a license for recognizable work of the bank in the provision of lending and financial services (Riyadh Bank Annual Report 2013). The mortgage and leasing arms of the firm were outstanding for the products and services offered by the company. The mortgage portfolio also recorded high growth rates. Safe and easy transfer of money remittances were also a notable achievement through the 'EZTRANSFER' that is by international company standards. Auto leasing products were also launched in the year with automated services that allow for consumers to get quick access to services where approvals are obtained within minutes of application (Riyadh Bank Annual Report 2013). Personal finance was provided at critical terms with the recording of the biggest financial services in the country. There was considerable growth for the bank with deposits increasing by over $4.8 \%$. Assets are increased by a total of $7.9 \%$ while loan advancements to the private sector rose by $11.7 \%$ that resulted in a profit growth of 13.9\% (Riyadh Bank Annual Report 2013).

In the year 2014, the bank strengthened its capital from SAR 15 billion to SAR 30 billion via share issuance, more importantly, the income grew by $10.26 \%$ from 2013 to 2014 (Riyadh Bank Annual Report 2014). The move assisted the bank, have a right level of capital, leverage off chances in the Kingdom, improved its solvency and sharpened its competitive edges to cement its leadership in the KSA banking sector. Furthermore, they have established digital platforms for service delivery, including the use of iPhone and Android application utility by its customers.

Further changes in long-term planning have overseen the restructuring of the organization and change of management. The move has led to report a strengthening of operational performance. To enhance its national presence, the bank has saudialized its labor with $100 \%$ of its female workers as at 2014 being locally based. This is concerning the bank's plan to promote and foster national talent via training and employment creation as $93 \%$ of its workers are local citizens. $23 \%$ of its workers are women, an initiative aimed at establishing gender equality in its employment policies.

The bank has over the past few years increased its assets in a move to increase his assets as the bank embarked on its riskaverse approach. Customers' deposits were increased by $7.1 \%$, while its investments have increased by 7.87 over the past three years. More loans were borrowed, and that was eminent via $1.75 \%$ increase over the past one year (Riyadh Bank Annual Report 2014).

\section{CONCLUSION}

Strategic information systems planning have been implemented on banking sector in the last few years. It is approved that SISP increase the efficiency of the services which leads to higher rate of performance, productivity, and customer satisfaction. SISP implemented through short-term and long-term plan and the benefits of SISP implementation exist through different banks. Some case studies of international banks which include Korea, Lebanon, and UAE are discussed to show how SISP plays a significant role over their process and activities. Riyadh Bank's annual report of 2010, 2011, 2012, 2013 and 2014 has been analyzed to demonstrate the progresses and improvements achieved every year and investigated what are the strategies behind these improvements.

\section{REFERENCES}

[1] Keivani, F., Jouzbarkand, M., Khodadadi, M., and Sourkouhi, Z., (2012). A General View on the EBanking. International Proceedings of Economics Development \& Research, Vol. 43, p62.

[2] Woods, L. (2016). How Online Banking Evolved into A Mainstream Financial Tool.

[3] Altameem, A., Aldrees, A., and Alsaeed, N, (2014). Strategic Information Systems Planning (SISP). Proceedings of the World Congress on Engineering and Computer Science 2014 Vol I WCECS 2014.

[4] Howard, P. 2008 The importance of an Information Strategy.

[5] Finkelstein. C. (n.d.). Bank Overhauls its Strategic Information System Plan in 3 Weeks. Kwangju Bank Strategic Information System Plan. Information Engineering Services Pty Ltd.

[6] Abdalkrim, G., and Khrais, L., (2013). The Impact of Strategic Planning on Online Banking: An Empirical Study in Saudi Arabia.

[7] Jalal, A., Nabi, H., and Marzooq, H., (2011). Evaluating the Impacts of Online Banking Factors on Motivating the Process of E-banking. Journal of Management and Sustainability. Vol. 1, No. 1; September 2011....

[8] Ghaziri, H. (1998) Information technology in the banking sector: Opportunities, threats and strategies.

[9] Al-Mudimigh, A. (2007). E-Business Strategy in an Online Banking Services: A Case Study. Journal of Internet Banking and Commerce, April 2007, vol. 12, no.1.

[10] Pita, Z.,Cheong, F., \& Corbitt, B. (2010). Strategic Information Systems Planning (SISP). International Journal for Strategic Decision Sciences, 1(2), 28-29.

[11] Riyadh Bank Annual Report 2011. (2011). Retrieved 27 April 2016, from http://Riyadh Bank Annual Report

[12] Riyadh Bank Annual Report 2010. (2010). Retrieved 27 April 2016, from http://Riyadh Bank Annual Report 2010.

[13] Riyadh Bank Annual Report 2013. (2013). Retrieved 27 April 2016, from http://Riyadh Bank Annual Report 2013

[14] Riyadh Bank Annual Report 2014. (2014). Retrieved 3 May 2016, from http://Riyadh Bank Annual Report 2014.

[15] Riyadh Bank Annual Report 2012. (2012). Retrieved 3 May 2016, from http://Riyadh Bank Annual Report 2012. 